http://journal.uinsgd.ac.id/index.php/biodjati

\title{
VEGETATION STRUCTURE, COMPOSITION, AND SOIL PROPERTIES OF DRY LAND ON ISLANDS IN BALIKPAPAN BAY, EAST KALIMANTAN
}

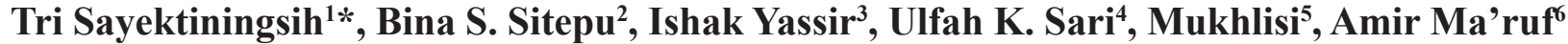

Received : November 17, 2019

Accepted : September 27, 2020

DOI: 10.15575/biodjati.v5i2.6434

${ }^{1}$ Forest Research and Development Institute of Makassar, Jl. Perintis Kemerdekaan Km. 16.5, Makassar, 90243

2,3,4,5,6 Research and Development Institute of Natural Resources Conservation Technology, Jl. Soekarno-Hatta Km. 38, Balikpapan, 76112

e-mail:

*1. t.sayekti@yahoo.com

²bssitepu@yahoo.com

3ishakyassir@gmail.com

4ulfahnazri@gmail.com

${ }^{5}$ m.mukhlis.i@gmail.com

ㅎdrhamirmaruf@yahoo.com

*Corresponding author

\begin{abstract}
Some small islands in Balikpapan Bay consist of dry land which may have different vegetation structure and composition. Our study was the first to uncover vegetation conditions and soil properties of dry land on small islands in Balikpapan Bay, which has never been conducted before. The research was carried out on Kalawasan and Karantina islands. Information on vegetation was obtained by applying a line transect method. Data on soil properties were collected by setting up 3 sampling plots in each transect of vegetation. Parameters used for analysing vegetation including relative density, relative frequency, relative dominance, Shannon-Wiener diversity index, evenness index, and similarity index. Meanwhile, data on soils were analysed descriptively. Trees on Kalawasan island were comprised of 241 individuals belonging to 21 species. There were 61 individuals (22 species) of trees on Karantina island. The diversity index of trees on Kalawasan and Karantina island was 2.55 and 2.72, respectively. The tree evenness index was 0.84 on Kalawasan island and 0.88 on Karantina island. The index of similarity for trees between the two islands was 0.21. Furthermore, the soil characteristics on Kalawasan and Karantina islands showed similarities. In general, soil in Kalawasan and Karantina islands could be categorised as marginal soil which was common in East Kalimantan. Considering the rapid loss of tropical forests in the mainland of Kalimantan indicates that the small islands of Balikpapan Bay play an important role in future biodiversity conservation in East Kalimantan.
\end{abstract}

Keywords: Balikpapan Bay, Dipterocarpaceae, dry land, line transect, soil

\section{Citation}

Sayektiningsih, T., Sitepu, B. S., Yassir, I., Sari, U. K., Mukhlisi \& Ma'ruf, A. (2020). Vegetation Structure, Composition, and Soil Properties of Dry Land on Islands in Balikpapan Bay, East Kalimantan. Jurnal Biodjati, 5(2), 199-213.

\section{INTRODUCTION}

Kalimantan which is part of Borneo has several small islands, such as Nunukan and those located in Balikpapan Bay, due to the influence of geological processes in the past
(Husein, 2017; Karim et al., 2019). Microclimate (Chahouki et al., 2012) and soil properties (Hattermann et al., 2018) affect the biophysical condition of the small islands, resulting in the difference in vegetation characteristics between small islands and the main- 


\section{JURNAL BIDDJATI}

http://journal.uinsgd.ac.id/index.php/biodjati

land. So far, studies on small islands have been attracting scholar interests since they are susceptible to the adverse effect of climate change (Taylor \& Kumar, 2016). Small islands are also at risk of alien species invasion (Russell et al., 2017). On the other hand, small islands sometimes have diverse species, including endemic species (Troia, 2012). It indicates that they should be taken into account in biodiversity conservation.

Balikpapan Bay is a semi-enclosed sea, stretching from Balikpapan city to Penajam Paser Utara regency $\left(116^{\circ} 42^{\prime}\right.$ - $116^{\circ} 50^{\prime} \mathrm{BT}$ dan $1^{\circ}-1^{\circ} 22^{\prime}$ LS), East Kalimantan. The region with a total area of $120 \mathrm{~km}^{2}$ consists of small islands namely Balang, Benawa Besar, Benawa Kecil, and Kalawasan (Pusat Pengendalian Pembangunan Ekoregion Kalimantan, 2016). Vegetation in Balikpapan Bay mainly consists of mangroves. There are 13 species of mangrove which dominated by Rhizophora apiculata, Sonneratia alba, Dysoxylum sp., Avicennia marina, and Ardisia sp. (Warsidi \& Endayani, 2017). However, some small islands in Balikpapan Bay consist of dry land which may have different vegetation structure and composition (Yassir, unpubl.).

Since Balikpapan Bay is known as the important habitat of mangrove and wildlife such as Dugong dugon and proboscis monkeys (Nasalis larvatus), studies have mostly dealt with these issues (Stark et al., 2012; Handayani et al., 2017; Warsidi \& Endayani, 2017). Information is also available on the geology of a particular small island such as Balang island (Usman \& Budiono, 2011). Accordingly, detailed information describing vegetation and soil condition of dry land on small islands in Balikpapan Bay remained unknown. According to Mirmanto (2014) who conducted a study on Natuna island, research on the vegetation of small islands could enrich the knowledge of vegetation in relation to its habitat. Besides, our findings will provide a new insight into biodiversity in Balikpapan Bay. Considering rapid development taken place around Balikpapan Bay (Hendriyani et al., 2013), it is important to know the initial ecological condition of the islands in order to provide information useful for future management (Sidiyasa, 2012). Therefore, the objective of this research was to investigate vegetation and soil properties of dry land on small islands in Balikpapan Bay.

\section{MATERIALS AND METHODS}

\section{Study Site}

This study was carried out in May 2018 in two different sites: Kalawasan and Karantina islands (Figure 1). Kalawasan island is the \pm 253.6 ha area in the north of Balikpapan Bay $\left(116^{\circ} 43^{\prime} 45^{\prime \prime} \mathrm{E}\right.$ and $\left.1^{\circ} 2^{\prime} 30^{\prime \prime} \mathrm{S}\right)$ close to the Mentawir village. Administratively, Kalawasan island is a part of Penajam Paser Utara regency. As many as 13.7 ha out of the total area of the island is dry land surrounded by mangrove forests. It is much flatter in the south, though it slopes steeply in the north and center of the dry land. Some parts of dry land, particularly in the north, are composed of dense Dicranopteris linearis. In the southern part of the island, there is a massive open area of an abandoned shrimp pond belonging to local communities. Moreover, Karantina island $\left(116^{\circ} 40^{\prime} 30^{\prime \prime} \mathrm{E}\right.$ and $\left.1^{\circ} 3{ }^{\prime} 45^{\prime \prime} \mathrm{S}\right)$ is much smaller than Kalawasan island ( \pm 2.5 ha) and consists of dry land entirely with flat topography. Karantina island is actually a small patch of land situated within the small and large stream system of Balikpapan Bay. Similar to Kalawasan island, the authorization of Karantina island is under Penajam Paser Utara regency. Dicranopteris linearis and bamboo (Bambusa sp.) grow abundantly on this island. 


\section{JURNAL BIDDJATI}

http://journal.uinsgd.ac.id/index.php/biodjati
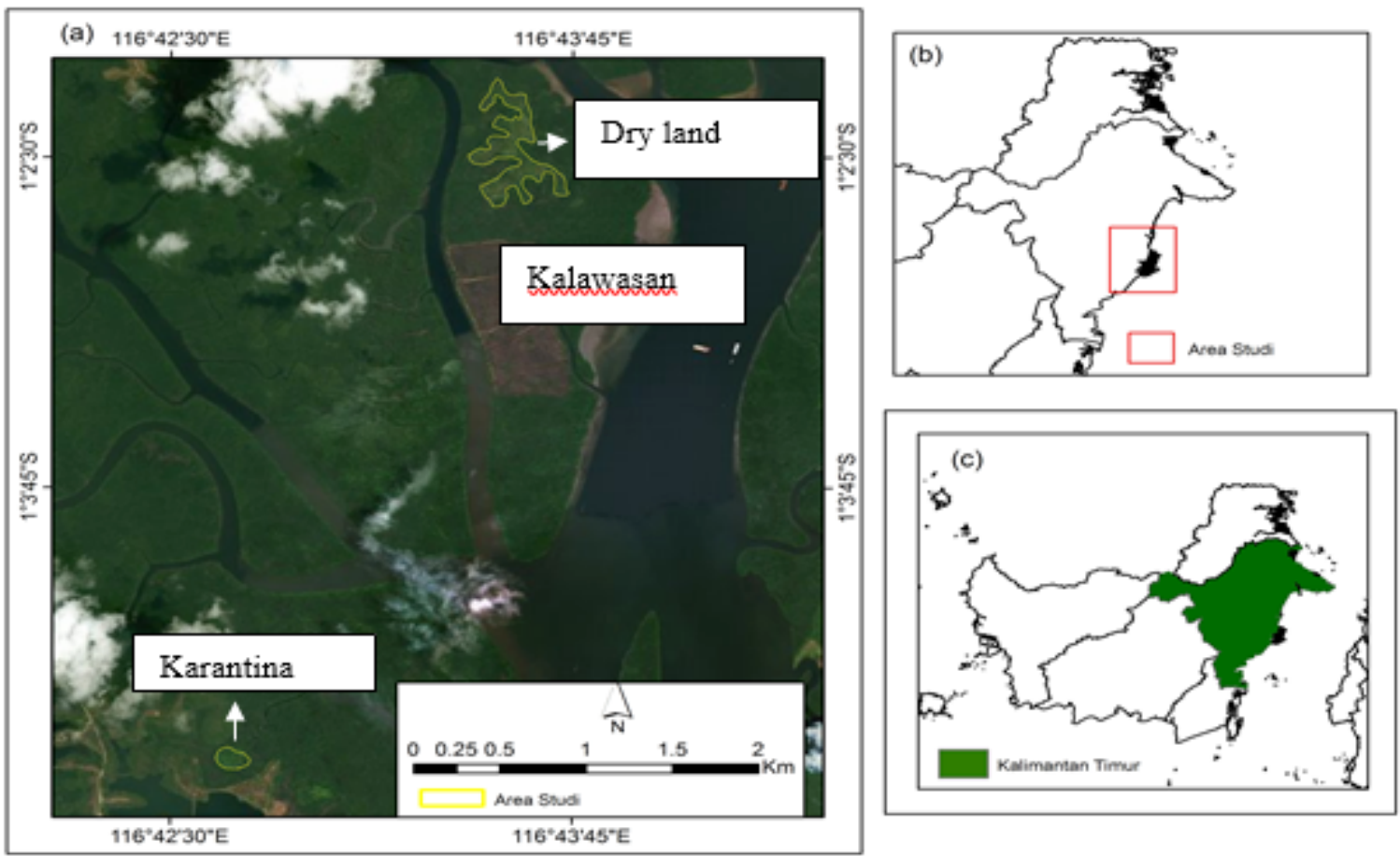

Figure 1. The research site, (a) Karantina and Kalawasan islands in Balikpapan Bay, (b) research site position towards the East Kalimantan map, (c) East Kalimantan in the Kalimantan map

\section{Data Collection}

Data were collected by applying a line transect method, as used in the terrestrial ecosystem (Hidayat, 2013; Nugraha \& Mustari, 2017; Rachman \& Hani, 2017). There were 3 and 2 transects in Kalawasan and Karantina islands, respectively. The shape of dry land influenced the number of transects installed both on the Karantina and Kalawasan islands. The length of transects was adjusted to the existing condition in the field. In each transect, plots were placed alternately for vegetation observation. In total, there were 26 plots on Kalawasan and 7 plots on Karantina. The difference in plot numbers was affected by the length of transects established.

We divided each plot into three subplots which were $20 \times 20 \mathrm{~m}$ for trees (diameter at breast height $(\mathrm{DBH}) \geq 10 \mathrm{~cm})$, non-climbing woody species), 5 x $5 \mathrm{~m}$ for saplings (DBH $<$ $10 \mathrm{~cm}$, height $\geq 1.5 \mathrm{~m}$, non-climbing woody species, and non-herbs), and $2 \times 2 \mathrm{~m}$ for seedlings (height $<1.5 \mathrm{~m}$, non-climbing woody species, and non-herbs) (modified from Arbainsyah et al., 2014). Information related to $\mathrm{DBH}$ and height was derived from the direct measurement of trees and saplings, whereas for seedlings name of species and its number were recorded. Plant samples were collected if we failed to identify the name of species during fieldwork. The collected samples were then labeled before they were put in plastic bags. Further identification was conducted in The Herbarium of Wanariset Samboja, East Kalimantan.

Soil samples were collected from each transect of vegetation. Three sampling points were set up in each transect, of which one at the center of the transect and 2 at the edge of the transect. We divided the soil profiles into three layers $A(0-10 \mathrm{~cm}), A B(10-20 \mathrm{~cm})$, and B $(20-30 \mathrm{~cm})$ following the method used by 


\section{JURNAL BIDDJATI}

http://journal.uinsgd.ac.id/index.php/biodjati

Yassir \& Buurman (2015). Thus, 45 soil samples were collected: 27 samples from Kalawasan island and 18 from Karantina island. All collected samples were placed in labeled plastic bags and transported to The Research Center of Tropical Forest Laboratory, Universitas Mulawarman, Samarinda, East Kalimantan for physical and chemical analysis.

\section{Data Analysis}

Species identification was based on books written by Keßler \& Sidiyasa (1999) and Bodegom et al. (1999). Some parameters used for vegetation analysis were relative density (RD), relative frequency (RF), and relative dominance (Rd) which were calculated by using the following formulas (Arbainsyah et al., 2014):

$\mathrm{RD}=$ (Individual number of each species/ Total individual number of all species) x $100 \%$ $\mathrm{RF}=$ (Number of quadrats where species found/Total number of quadrats) x 100\%

$\mathrm{Rd}=($ Dominance of certain species/Total dominance of all species) x 100\%

Important value index (IVI) for trees and saplings was obtained by calculating the sum of $\mathrm{RD}, \mathrm{RF}$, and $\mathrm{Rd}$, whereas IVI for seedlings was measured using the formula $\mathrm{RD}+\mathrm{RF}$ (Bonham, 2013).

We applied the Shannon-Wiener diversity index $\left(\mathrm{H}^{\prime}\right)$ and Pielou evenness index (E) to measure species diversity and evenness indices. Meanwhile, the similarity index (Is) was used to compare the plant communities between sites. The formulas used were shown below (Odum, 1993):

$$
H^{\prime}=-\sum_{i=1}^{n} \text { pi ln pi }
$$

Where: H' is Shannon-Wiener diversity index, pi is number of individuals of species $i$ divided by total number of individuals, and $\mathrm{ln}$ is natural logarithm.

$\mathrm{E}=\mathrm{H}^{\prime} / \ln \mathrm{S}$

Where: H' is Shannon-Wiener diversity index, $\mathrm{S}$ is number of species, and $\ln$ is natural logarithm.

Is $=[2 \mathrm{C} /(\mathrm{A}+\mathrm{B})] \mathrm{x} 100$

Where: $C$ is sum of species found in two communities, $\mathrm{A}$ is sum of species in site $\mathrm{A}$, and $\mathrm{B}$ is sum of species in site $B$.

The interpretation of soil properties was provided by Balai Penelitian Tanah (Institute of Soil Research) (Sulaeman et al., 2005). Chemical soil properties included bulk density (g/cc, only horizon $\mathrm{A}), \mathrm{pH}, \mathrm{C}$ organic $(\%)$, $\mathrm{N}(\%), \mathrm{C} / \mathrm{N}(\%), \mathrm{P}_{2} \mathrm{O}_{5}(\mathrm{ppm})$, and $\mathrm{K}_{2} \mathrm{O}(\mathrm{ppm})$. The measurement of physical soil properties was conducted towards silts, clays, and sands. Data related soils were illustrated by tables and analysed descriptively.

\section{RESULTS AND DISCUSSION}

\section{Composition and Structure of Vegetation}

Several trees of Kalawasan and Karantina islands were commonly found in secondary and old secondary forests and they are even typical species of primary forest of Kalimantan (Sidiyasa, 2009; Yassir \& Arbainsyah, 2014; Rahayu et al., 2017). We found 241 individuals of trees representing 14 families, recorded from the area of 1.04 ha on Kalawasan island. Myrtaceae was the most abundant family with the greatest number of species ( 6 species, 4 genera). It was followed by Fabaceae (2 species, 2 genera) and Dipterocarpaceae (2 species, 2 genera) (Figure 2). The family of Myrtaceae also had the highest number of trees (55 individuals). Fabaceae (36 individuals) and Lamiaceae (26 individuals) were the second and the third most dominant family on Kalawasan island, respectively. Furthermore, Karantina island was composed of 61 individuals of trees (15 families) identified in the 


\section{JURNAL BIDDJATI}

http://journal.uinsgd.ac.id/index.php/biodjati

0.28 ha area. Dipterocarpaceae ( 5 species, 4 genera), Myrtaceae ( 3 species, 2 genera), and Anacardiaceae ( 2 species, 2 genera) were the top three families with the highest number of species (Figure 2). Although Dipterocarpaceae was the most dominant family, it did not make the family harboured many trees. Ebenaceae was the family with the highest number of trees (12 individuals), which was only represented by one species, Diospyros borneensis.
We recorded 324 individuals (15 families) of saplings on Kalawasan island, which were mainly dominated by the family of Myrtaceae (6 species, 3 genera). Seventeen (17) individuals of saplings were recorded on Karantina island, which belongs to 7 families. Each family of saplings Karantina island was comprised by single species. In terms of seedlings, there were 676 individuals and 33 individuals of seedlings on Kalawasan and Karantina islands, respectively.

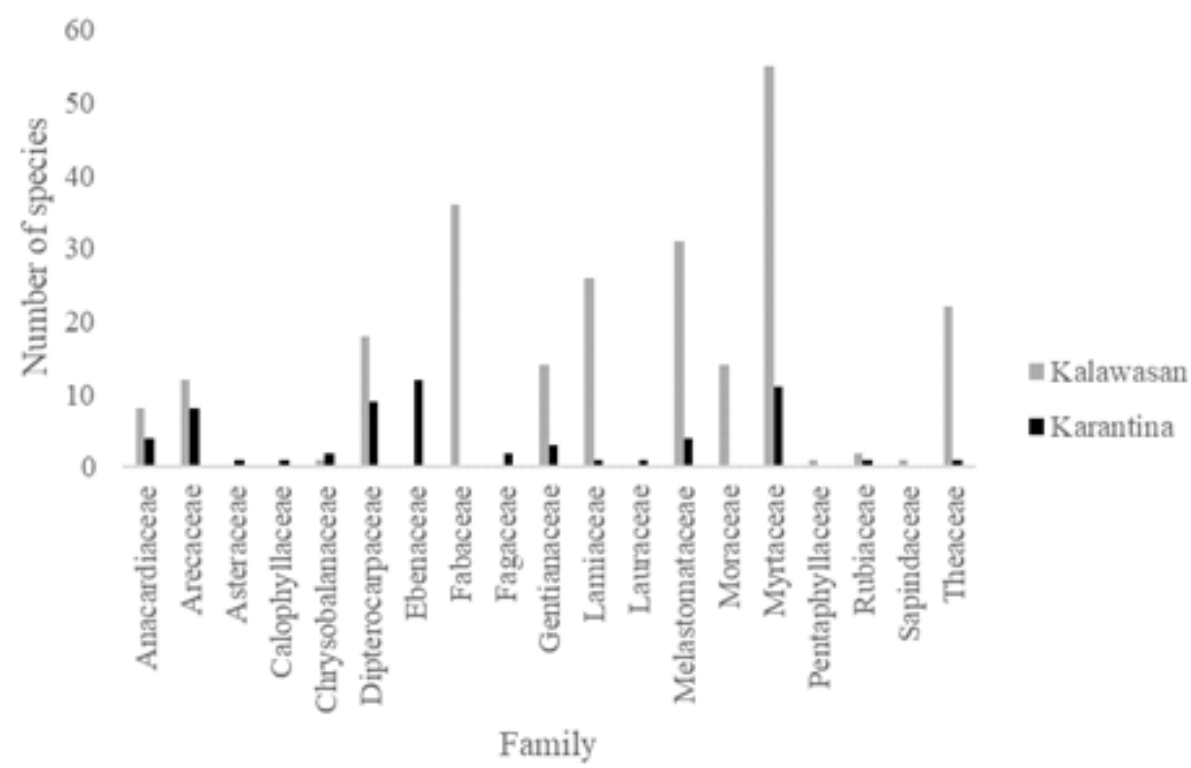

Figure 2. Number of tree species on Kalawasan and Karantina islands

The total density of trees on Kalawasan island was 231.73 trees/ha, while Karantina island was 217.86 trees/ha. Syzygium $c f$. nigricans, Acacia mangium, and Pternandra galeata had the highest density on Kalawasan island. While Diospyros borneensis, Oncorperma horridum, and Syzygium $c f$. nigricans were the three densest species on Karantina island. In general, Kalawasan and Karantina islands had remarkably lower tree density than that in previously disturbed forests. Toma et al. (2017) measured tree density in logged and burned forest areas in Bukit Soeharto, East Kalimantan. They found tree density was 515 trees/ha and was dominated by pioneer species. In similar, Rahayu et al. (2017) found that tree density in plots previously affected by the fire and illegal logging in the research forest of Samboja was 597 trees/ha. Human disturbance is a driver for the low tree density on both islands. In fact, the dryland forest on Kalawasan island was a subject of agriculture in the past, even though it was then abandoned. Table 1 below summarises vegetation conditions on Kalawasan and Karantina islands. 


\section{JURNAL BIDDJATI}

http://journal.uinsgd.ac.id/index.php/biodjati

Table 1. Overview of seedlings, saplings, and trees on Karantina and Kalawasan islands

\begin{tabular}{|c|c|c|c|c|c|c|}
\hline Site and Level & Density/ha & $\begin{array}{c}\text { Basal area } \\
\left(\mathrm{m}^{2} / \mathrm{ha}\right)\end{array}$ & $\begin{array}{c}\text { No. of } \\
\text { species }\end{array}$ & $\begin{array}{l}\text { No. of } \\
\text { genus }\end{array}$ & $\begin{array}{l}\text { No. of } \\
\text { family }\end{array}$ & $\begin{array}{c}\text { No. of } \\
\text { individuals }\end{array}$ \\
\hline \multicolumn{7}{|c|}{ Kalawasan } \\
\hline Seedling & 65,000 & - & 14 & 13 & 6 & 676 \\
\hline Sapling & $4,984.62$ & 128.70 & 23 & 21 & 15 & 324 \\
\hline Tree & 231.73 & 89.32 & 21 & 19 & 14 & 241 \\
\hline \multicolumn{7}{|c|}{ Karantina } \\
\hline Seedling & $11,785.71$ & - & 5 & 5 & 5 & 33 \\
\hline Sapling & 971.43 & 10.87 & 7 & 7 & 7 & 17 \\
\hline Tree & 217.86 & 42.36 & 22 & 21 & 15 & 61 \\
\hline
\end{tabular}

The number of individuals of species tended to decline from seedlings to saplings on Karantina island. Although the number of individuals of species increased from saplings to trees, $91.80 \%$ of trees had no seedlings. Species with no seedlings indicated that they were sensitive to disturbance and if there is no appropriate management they will be more susceptible to local extinction in the near future (Gurmessa, et al., 2012; Datta \& Devi, 2013). From the general assessment of site condition, Dicranopteris linearis could be considered as the main constraint on plant regeneration. $D$. linearis is a native invasive fern characterised by long rhizomes grown in the terrestrial ecosystem, greenish-brown stem, and growing on the ground or climbing on trees (Sofiyanti et al., 2019). It covers large open or abandoned areas which commonly have warm temperature and high level of light availability (Wahyuni et al., 2016). Shono et al. (2006) noted that once $D$. linearis formed a dense thicket it would impede the regeneration of woody plant species by inhibiting light penetration. Based on their experiment in a restored area in Singapore, following a month of the removal of $D$. linearis, woody plant species started to regenerate, increasing the number of plant diversity. The negative impact of $D$. linearis was also confirmed by
Yassir et al. (2010) who found that $D$. linearis corresponded to acid soil which had a detrimental effect on other plants.

There was also a decline in the number of individuals of species from seedlings to saplings on Kalawasan island. As Karantina island, the development of seedlings on Kalawasan island was hindered by Dicranopteris linearis. Another reason for the decrease in saplings was the presence of pioneer tree species, such as Pternandra galeata and Vitex pinnata. Hidayat (2013) mentioned that pioneer trees have the ability to grow rapidly. However, because of the short lifespan, they will disappear before reaching the age of 30 years. The reduction of pioneer trees will eventually affect the composition of vegetation on the next stage, thereby contributing to the dynamics of vegetation (Ademoh et al., 2017)

The dryland forest of Kalawasan and Karantina islands was represented by young vegetation. The mean of tree diameter on Kalawasan island was $14.4 \mathrm{~cm}(\mathrm{Sd}=4.58)$ and $20.88 \mathrm{~cm}(\mathrm{Sd}=10.36)$ on Karantina island. Trees with diameters $10-19 \mathrm{~cm}$ were more dominant on both islands (Figure 3). The tree diameter distribution on Kalawasan and Karantina islands followed the shape of reversed $\mathrm{J}$ informing that natural regeneration on both sites was well occurred (Yassir \& 


\section{JURNAL BIDDJATI}

http://journal.uinsgd.ac.id/index.php/biodjati

Arbainsyah, 2014). A similar pattern of diameter distribution was also noted in Sungai Wain primary forest (Sidiyasa, 2009), research forest of Samboja (Rahayu et al., 2017), and secondary forest of Samboja Lestari (Yassir \& Arbainsyah, 2014). Tree height on Kalawasan island varied from 3 to $17 \mathrm{~m}$ (mean $=10.41$ $\mathrm{m}, \mathrm{Sd}=3.30$ ). Trees with a height of 5 to 9 $\mathrm{m}$ were more abundant (Figure 4 ). We noted
Cotylelobium melanoxylum was the highest tree. This species is known as an emergent tree and found in areas with sandy soils. Tree height on Karantina island was between 7 and $20 \mathrm{~m}($ mean $=12.91 \mathrm{~m}, \mathrm{Sd}=3.38)$ with Fragraea renae as the highest tree species. Trees $>14 \mathrm{~m}$ in height were more common on the island.

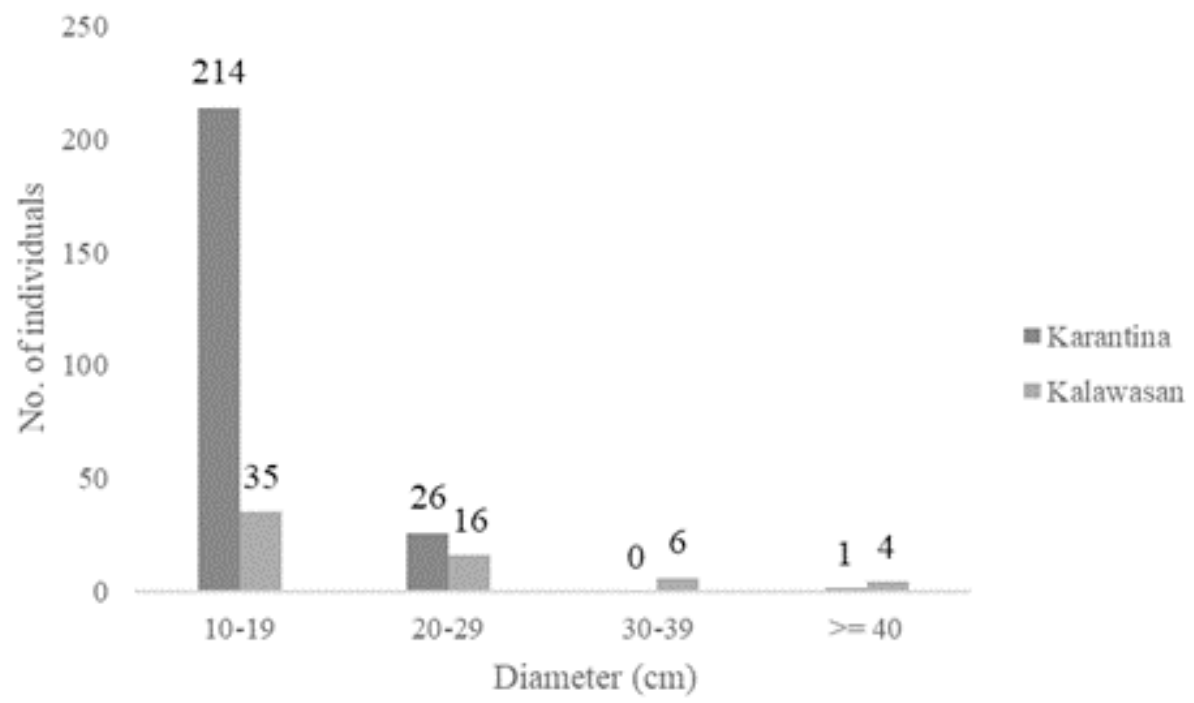

Figure 3. The distribution of tree diameter on Kalawasan and Karantina islands

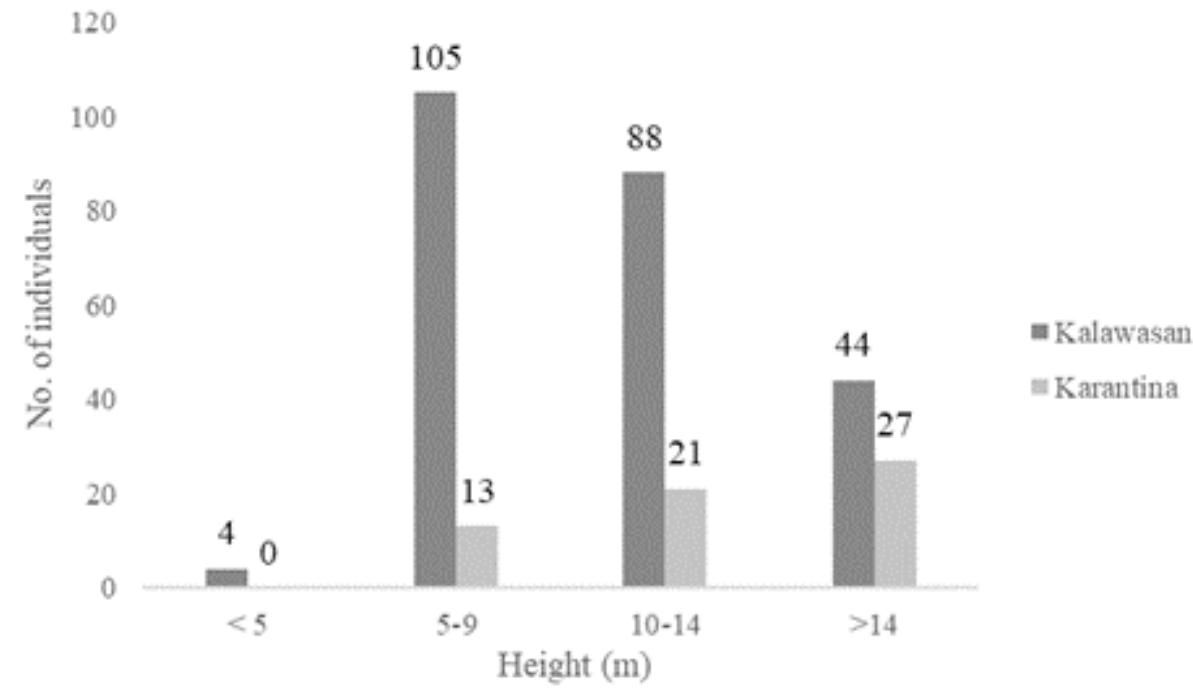

Figure 4. The distribution of tree height on Kalawasan and Karantina islands 


\section{JURNAL BIDDJATI}

http://journal.uinsgd.ac.id/index.php/biodjati

The presence of Acacia mangium as exotic species on Kalawasan island showed that the island experienced a disturbance in the past. Based on the number of trees (33 individuals) and the range of diameter (20-29 $\mathrm{cm})$, A. mangium was invasive species to the island (Koutika, 2019; Aguiar et al., 2014). However, considering the vegetation composition dominated by native pioneer tree species, it could be said that the growth of $A$. mangium was suppressed. It was proven by none of $A$. mangium seedlings found and only had 4 individuals in the sapling level. Apart from its drawback, A. mangium has a crucial role in improving soil fertility through the nitrogen fixation process (Machado et al., 2017; Tchichelle et al., 2017).

The family of Dipterocarpaceae shows that the process towards the late-successional stage is ongoing. Nevertheless, the number of trees does not show the domination of Dipterocarpaceae on both sites. It is likely that the trees are the remaining population of the initial forest. Shorea balangeran and Dipterocarpus tempehes are considerable examples of Dipterocarpaceae in Balikpapan Bay since IUCN has listed them as critically endangered due to excessive timber harvesting in their natural habitat. Shorea balangeran is mainly distributed in heath forest and swamp forest. One of the important habitats of Shorea balangeran in East Kalimantan is the heath forest located along the coastal area of Samboja. While Shorea balangeran is predominantly found in heath forest and swampy areas, Dipterocarpus tempehes, which is endemic to Borneo, mostly inhabits areas close to river banks.

\section{Important Value, Diversity, Evenness, and Similarity}

The IVI of trees on Kalawasan island was $1.66 \%$ to $53.95 \%$, while on Karantina island IVI varied from $4.65 \%$ to $72.63 \%$. Syzygium cf. nigricans (IVI 53.95\%) from Myrtaceae and Diospyros borneensis (IVI $72.63 \%$ ) from Ebenaceae were the most dominant tree species on Kalawasan and Karantina islands, respectively. Pternandra galeata (62.24\%) made up the highest IVI of saplings on Kalawasan island, followed by Fagraea renae (IVI 39.24\%) and Vitex pinnata (IVI 33\%). Oncosperma horridum from Arecaceae grew in abundance and had the highest IVI on Karantina island, accounted for $137.21 \%$ of IVI. Ixora sp. (IVI 44.67\%) and Diospyros borneensis (IVI 42.07\%) then ranked second and third. For seedlings, Syzygium cf. nigricans was the most dominant species on both islands (Table 2 and 3 ). In our case, trees with the highest IVI also had the highest value of relative density, relative frequency, and basal area. Sidiyasa (2009) stated that species with the highest IVI was well adapted to the environment since they could employ resources, such as light and nutrition, in an efficient manner.

The diversity index corresponds to species diversity (Haryadi et al., 2019). Table 4 shows that both islands had low diversity for seedlings and moderate for saplings and trees (Odum, 1993) (Table 2). Although in fact, Kalawasan and Karantina islands were similar in terms of tree diversity, the tree diversity on Karantina island was slightly higher than Kalawasan island. The dry land pattern on Kalawasan island which is bordered by mangrove forests may limit the availability of seed sources of terrestrial plants. Like the seedling diversity index, the seedling evenness index was low on the two islands. It indicated that certain species were more abundant. In contrast to seedlings, the evenness index for saplings and trees was high (Table 4). According to Arini \& Wahyuni (2016), the evenness index is associated with community stability. 


\section{JURNAL BIDDJATI}

http://journal.uinsgd.ac.id/index.php/biodjati

Table 2. Important value index of species on a dry land of Kalawasan island

\begin{tabular}{|c|c|c|}
\hline Level & Species & IVI $(\%)$ \\
\hline \multirow[t]{10}{*}{ Seedling } & Syzygium cf. nigricans & 101.46 \\
\hline & Syzygium lineatum (DC) Merr. \& Perry & 39.14 \\
\hline & Rhodamnia cinerea Jack & 10.59 \\
\hline & Timonius flavescens (Jack) Baker & 7.99 \\
\hline & Pternandra galeata (Korth.) Ridl & 7.70 \\
\hline & Syzygium staffiana & 4.66 \\
\hline & Schima wallichii (DC.) Korth & 4.07 \\
\hline & Buchanania arborescens (Blume) Blume & 3.48 \\
\hline & Diplospora cf. malaccensis & 3.48 \\
\hline & Fagraea racemose Jack ex Wall & 3.48 \\
\hline \multirow[t]{10}{*}{ Sapling } & Pternandra galeata (Korth.) Ridl & 62.24 \\
\hline & Fagraea renae K.M. Wong \& Sugau & 39.24 \\
\hline & Vitex pinnata $\mathrm{L}$. & 33.00 \\
\hline & Cotylelobium melanoxylum (Hook.f) Pierre & 29.21 \\
\hline & Syzygium cf. nigricans & 22.66 \\
\hline & Syzygium lineatum (DC) Merr. \& Perry & 17.58 \\
\hline & Rhodamnia cinerea Jack & 16.85 \\
\hline & Timonius flavescens (Jack) Baker & 15.31 \\
\hline & Schima wallichii (DC.) Korth & 12.44 \\
\hline & Buchanania arborescens (Blume) Blume & 11.72 \\
\hline \multirow[t]{10}{*}{ Tree } & Syzygium cf. nigricans & 53.95 \\
\hline & Acacia mangium Willd. & 48.60 \\
\hline & Pternandra galeata (Korth.) Ridl & 33.15 \\
\hline & Vitex pinnata $\mathrm{L}$. & 29.22 \\
\hline & Schima wallichii (DC.) Korth & 24.34 \\
\hline & Cotylelobium melanoxylum Pierre & 17.71 \\
\hline & Rhodamnia cinerea Jack & 17.15 \\
\hline & Fagraea renae K.M. Wong \& Sugau & 17.13 \\
\hline & Artocarpus integer (Thunb.) Merr & 14.34 \\
\hline & Buchanania arborescens (Blume) Blume & 12.11 \\
\hline
\end{tabular}

Table 3. Important value index of species on a dry land of Karantina island

\begin{tabular}{clc}
\hline Level & & IVI (\%) \\
\hline Seedling & Syzygium cf. nigricans & 128.79 \\
& Ixora sp. & 18.56 \\
& Diospyros borneensis Hiern. & 18.56 \\
& Leea indica (Burm.f.) Merr. & 18.56 \\
Sapling & Hopea mengerawan Miq & 15.53 \\
& Oncosperma horridum (Griff.) Scheff. & 137.21 \\
& Ixora sp. & 44.67 \\
& Diospyros borneensis Hiern & 42.07 \\
& Dipterocarpus tempehes Slooten. & 20.13 \\
Eurycoma longifolia Jack & 19.04 \\
Leea indica (Burm.f.) Merr. & 18.48 \\
Pternandra galeata (Korth.) Ridl & 18.42 \\
Diospyros borneensis Hiern. & 72.63 \\
Syzygium cf. nigricans & 38.90 \\
& Oncosperma horridum (Griff.) Scheff. & 25.47 \\
& Syzygium sp.1 & 21.89 \\
& Cotylelobium melanoxylum Pierre & 19.10 \\
& Fagraea renae K.M.Wong \& Sugau & 18.70 \\
Pternandra galeata (Korth.) Ridl. & 14.10 \\
Buchanania arborescens (Blume) Blume & 13.47 \\
& Licania splendens (Korth.) Prance & 7.48 \\
Hopea mengerawan Miq. & 7.11 \\
\hline
\end{tabular}




\section{JURNAL BIDDJATI}

http://journal.uinsgd.ac.id/index.php/biodjati

Table 4. The comparison of diversity and evenness on the two research sites

\begin{tabular}{lcc}
\hline \multicolumn{1}{c}{ Site and Level } & $\begin{array}{c}\text { Shannon-Wiener } \\
\text { Diversity Index }\end{array}$ & Evenness Index \\
\hline Seedling & Kalawasan & \\
Sapling & 0.94 & 0.36 \\
Tree & 2.61 & 0.83 \\
& 2.55 & 0.84 \\
Seedling & Karantina & \\
Sapling & 0.80 & 0.50 \\
Tree & 1.64 & 0.84 \\
\hline
\end{tabular}

There was a significant difference between sites in line with vegetation composition, represented by a low score of similarity index of which 0.11 for seedlings, 0.13 for saplings, and 0.21 for trees. We noted that there was only single species recorded on both study sites for seedlings, Syzygium $c f$. nigricans. For saplings, Pternandra galeata and Eurycoma longifolia were two species investigated on both islands. In addition, there were 9 species of trees on Kalawasan and Karantina islands. The low similarity index was primarily because of the distance between sites, which was about $6 \mathrm{~km}$. This is consistent with Sidiyasa (2009) who conducted a study in Sungai Wain Protection Forest. Sidiyasa (2009) found that vegetation composition between plots located in the north part and in the south part of the forest tended to differ compared to those located in the same area. Tata \& Pradjadinata (2013) through their research in Central Kalimantan also revealed that the high similarity of vegetation composition would be exhibited by two adjacent habitats.

\section{Soil Properties}

Soil chemical analysis was presented in Table 5. From the A to B horizon, soil pH decreased gradually on both islands. Compared to other study sites, soil $\mathrm{pH}$ on Kalawasan and Karantina was lower than that of soil $\mathrm{pH}$ Sayektiningsih et al. in other forests in East Kalimantan such as the secondary forest of Samboja Lestari and Sungai Wain protection forest (Yassir \& Buurman, 2015). A study by Yuliana (2012) found that soil with low $\mathrm{pH}$ content can jeopardise the growth of plants since it reduces the availability of essential nutrients. However, Fajri \& Saridan (2012), who conducted research in Labanan forest, East Kalimantan, stated that soil $\mathrm{pH}$ was not a single factor in determining plant growth. They argued that the $\mathrm{Al}^{3+}$ level also affected the condition. Low $\mathrm{pH}$ is one of the characteristics belonging to Ultisols which are widely distributed in East Kalimantan (Suharta, 2010).

The $\mathrm{C}$ organic content was moderate for $\mathrm{A}$ and $\mathrm{AB}$ horizons and it was low for the $\mathrm{B}$ horizon on Kalawasan island. It slightly differed from Karantina island, in which only the A horizon had moderate $\mathrm{C}$ organic content. Nevertheless, the $\mathrm{C}$ organic content on both islands decreased along with the increase in soil depth. The high $\mathrm{C}$ organic content of topsoil might result from the decomposition process of litters. In this study, bulk density was $1.03 \mathrm{~g} / \mathrm{cc}$ on Kalawasan island and $0.99 \mathrm{~g} / \mathrm{cc}$ on Karantina island, indicating the soils had good permeability and density (Soufian et al., 2015).

The amount of $\mathrm{N}$, available $\mathrm{P}$ and $\mathrm{K}$ on both islands decreased from the A to B horizon. Particularly P, P content found on Kalawasan and Karantina islands was also simi- 


\section{JURNAL BIDDJATI}

http://journal.uinsgd.ac.id/index.php/biodjati

lar to the $\mathrm{P}$ content common in Kalimantan, which tended to decline from topsoil to subsoil (Suharta, 2010). The result, based on Yassir \& Arbainsyah (2014) study, was due to the lack of $\mathrm{P}$ stocks in soils, which was affected by the low P material in parent rock (Suharta, 2010). In contrast to $\mathrm{P}$, while there was a decrease in $\mathrm{K}$ from topsoil to subsoil, the amount of $\mathrm{K}$ on both islands was high. Surprisingly, available $\mathrm{K}$ on Karantina island was higher than that on Kalawasan island. The reason for this is because the weathering process on Karantina island is still ongoing at a moderate level, thereby influencing the availability of minerals containing K (Suharta, 2010). The fair amount of N, P, and $\mathrm{K}$ in soils is crucial for the plant growth. $\mathrm{P}$, for example, is effective in assisting the plant tissue and root development (Soufian et al., 2015). Chahouki et al. (2012) even revealed that $\mathrm{N}$ and $\mathrm{P}$ were able in controlling the distribution of vegetation.

The soil texture of Kalawasan and Karantina islands was dominated by the clay fraction. The high content of clay might be a reason why $\mathrm{K}$ on both islands was abundant in comparison to P. The clay fraction increased from topsoil to subsoil, while the sand fraction decreased. The same pattern is also found in Samarinda, Sangasanga, Muarajawa, and Balikpapan (Sasamba) (Prasetyo et al., 2001). Interestingly, the fraction of silt tended to fluctuate on Kalawasan island and slightly increase on Karantina island. Information on soil properties is presented in Tables 5 and 6.

Table 5. Chemical soil properties on a dry land of Kalawasan and Karantina islands

\begin{tabular}{cccccccc}
\hline & \multicolumn{7}{c}{ Mean } \\
\cline { 2 - 8 } Site & $\mathrm{Bd}(\mathrm{g} / \mathrm{cc})$ & $\mathrm{pH}$ & $\mathrm{C}$ organic & $\mathrm{N}(\%)$ & $\mathrm{C} / \mathrm{N}(\%)$ & $\begin{array}{c}\mathrm{P}_{2} \mathrm{O}_{5} \\
(\mathrm{ppm})\end{array}$ & $\mathrm{K}_{2} \mathrm{O}(\mathrm{ppm})$ \\
\hline & & \multicolumn{7}{c}{ Kalawasan } \\
$\mathrm{A}(0-10 \mathrm{~cm})$ & 1.03 & $4.29 \pm 0.18$ & $2.73 \pm 0.22$ & $0.14 \pm 0.02$ & $19.5 \pm 0.01$ & $5.12 \pm 1.17$ & $62.96 \pm 3.66$ \\
$\mathrm{AB}(10-20 \mathrm{~cm})$ & & $4.26 \pm 0.17$ & $2.20 \pm 0.26$ & $0.12 \pm 0.01$ & $18.44 \pm 0.01$ & $3.29 \pm 0.34$ & $49.15 \pm 5.71$ \\
$\mathrm{~B}(20-30 \mathrm{~cm})$ & & $4.15 \pm 0.16$ & $1.49 \pm 0.28$ & $0.10 \pm 0.01$ & $14.9 \pm 0.01$ & $0.95 \pm 0.27$ & $41.62 \pm 7.22$ \\
& & & Karantina & & \\
$\mathrm{A}(0-10 \mathrm{~cm})$ & 0.99 & $4.12 \pm 0.23$ & $2.85 \pm 0.18$ & $0.18 \pm 0.04$ & $16.26 \pm 3.43$ & $2.34 \pm 1.19$ & $119.62 \pm 52.63$ \\
$\mathrm{AB}(10-20 \mathrm{~cm})$ & & $4.06 \pm 0.24$ & $1.84 \pm 0.25$ & $0.12 \pm 0.02$ & $15.10 \pm 2.50$ & $0.96 \pm 0.46$ & $78.36 \pm 29.79$ \\
$\mathrm{~B}(20-30 \mathrm{~cm})$ & & $4.03 \pm 0.14$ & $1.46 \pm 0.30$ & $0.10 \pm 0.01$ & $15.06 \pm 3.53$ & $0.77 \pm 0.67$ & $62.00 \pm 22.27$ \\
\hline
\end{tabular}

Table 6. Physical soil properties on a dry land of Kalawasan and Karantina islands

\begin{tabular}{|c|c|c|c|}
\hline \multirow{2}{*}{ Site } & \multicolumn{3}{|c|}{ Mean } \\
\hline & Silt & Clay & Sand \\
\hline \multicolumn{4}{|c|}{ Kalawasan } \\
\hline $\mathrm{A}(0-10 \mathrm{~cm})$ & $21.63 \pm 9.03$ & $23.21 \pm 6.79$ & $55.16 \pm 11.32$ \\
\hline $\mathrm{AB}(10-20 \mathrm{~cm})$ & $19.04 \pm 5.75$ & $27.43 \pm 4.12$ & $53.53 \pm 8.78$ \\
\hline B $(20-30 \mathrm{~cm})$ & $21.02 \pm 6.66$ & $28.6 \pm 4.59$ & $50.38 \pm 7.94$ \\
\hline \multicolumn{4}{|c|}{ Karantina } \\
\hline $\mathrm{A}(0-10 \mathrm{~cm})$ & $29.56 \pm 2.68$ & $34.40 \pm 5.13$ & $36.14 \pm 7.72$ \\
\hline $\mathrm{AB}(10-20 \mathrm{~cm})$ & $29.96 \pm 3.63$ & $37.00 \pm 5.70$ & $33.04 \pm 8.99$ \\
\hline B $(20-30 \mathrm{~cm})$ & $30.00 \pm 9.61$ & $37.92 \pm 7.65$ & $32.08 \pm 8.60$ \\
\hline
\end{tabular}




\section{JURNAL BIDDJATI}

http://journal.uinsgd.ac.id/index.php/biodjati

The finding of Dipterocarpaceae particularly Shorea balangeran and Dipterocarpus tempehes reveals that small islands of Balikpapan Bay matter for conservation; as habitat and natural laboratory for studying the succession of vegetation on small islands. By considering the rapid loss of tropical forests in the main island of Kalimantan, it implies that small islands of Balikpapan Bay play an important role in future biodiversity conservation in Kalimantan, particularly in East Kalimantan. Therefore, the idea to stipulate Balikpapan Bay as a conservation area should be continued because it is not only conserved biodiversity inside but also it will protect landscape entirely. Establishing a conservation area, such as a marine protected area, is also an effort to prevent the environmental impacts caused by industrial development around Balikpapan Bay.

Our study was the first to uncover vegetation condition and soil properties on dry land in Balikpapan Bay, which has never been conducted before. Dryland in Balikpapan Bay is vulnerable to be converted into agricultural land by local communities in the present day. They may encroach the land once there is no sign of human activities. Regarding the low intensity of patrol from forest rangers around Balikpapan Bay, it is important to encourage activities relating to conservation on the island by involving students, the local communities, NGOs, and local government.

\section{ACKNOWLEDGEMENTS}

We would like to express our gratitude to the Ministry of Environment and Forestry for research funding 2018 so that we can find and explore a new exciting place beneficial for future biodiversity conservation in East Kalimantan. We thank to colleagues who have helped us during data collection, speci- men identification, and soil preparation. Special thank is also addressed to Yayasan Arsari Djojohadikusumo for assisting soil analysis. Lastly, the authors would thank to reviewers for helpful feedbacks.

\section{REFERENCES}

Ademoh, F. O., Muoghalu, J. I. \& Brian, O. (2017). Temporal Pattern of Tree Community Dynamics in a Secondary Forest in Southwest Nigeria, 29 Years After a Ground Fire. Global Ecology and Conservation, 9(1), 148-170.

Aguiar, A., Barbosa, R. I., Barbosa, J. B. F. \& Mourao, M. (2014). Invasion of Acacia mangium in Amazonian savannas following planting for forestry. Plant Ecology and Diversity, 7(1-2), 359-369.

Arbainsyah, de Iongh, H. H., Kustiawan, W. \& de Snoo, G. R. (2014). Structure, Composition and Diversity of Plant Communities in FSC-certified, Selectively logged forests of Different Ages Compared to Primary Rain Forest. Biodiversity and Conservation, 23(10), 2445-2472.

Arini, D. I. D. \& Wahyuni, N. I. (2016). Kelimpahan Tumbuhan Pakan Anoa (Bubalus sp.) di Taman Nasional Bogani Nani Wartabone. Jurnal Penelitian Kehutanan Wallacea, 5(1), 91-102.

Bodegom, S., Pelser, P. B. \& Sidiyasa, K. (1999). Semai-Semai Pohon Hutan Sekunder di Kalimantan Timur, Indonesia. MOFEC-Tropenbos-Kalimantan Project.

Bonham, C. D. (2013). Measurements for Terestrial Vegetation. Colorado: Willey-Black Well.

Chahouki, M. A. Z., Khojasteh, F. \& Tavili, A. (2012). Distribution of Vegetation Type according to Edaphic Properties and 


\section{JURNAL BIDDJATI}

http://journal.uinsgd.ac.id/index.php/biodjati

Topography in Iran. Pol. J. Environ. Stud, 21(4), 1071-1077.

Datta, G. \& Devi, A. (2013). Plant Diversity, Population Structure, and Regeneration Status in Disturbed Tropical Forests in Assam, Northeast India. Journal of $\mathrm{FO}_{\mathrm{O}}$ restry Research, 24(4), 715-720.

Fajri, M. \& Saridan, A. (2012). Kajian Ekologi Parashorea malaanonan Merr di Hutan Penelitian Labanan Kabupaten Berau, Kalimantan Timur. Jurnal Penelitian Dipterokarpa, 6(2), 141-154.

Gurmessa, F., Soromessa, T. \& Kelbessa, E. (2012). Structure and Regeneration Status of Komto Afromontane Moist Forest, East Wollega Zone, West Ethiopia. Journal of Forestry Research, 23(2), 205-216.

Handayani, C. N. N., Estradivari, Daniel, D., Hadian, O., Faisal, K. F., Sucipto, D. \& Maulida, P. (2017). Identifikasi Lokasi Prioritas Konservasi di Indonesia Berdasarkan Konektivitas Darat-Laut. Coastal and Ocean Journal, 1(2), 13-26.

Haryadi, Sunarto \& Sugiyarto. (2019). Vegetation Analysis of the Secondary Forest Area in Cangkringan Resort, Mount Merapi National Park. Jurnal Biodjati, 4(1), 50-57.

Hattermann, D., Romermann, M. B., Otte, A. \& Eckstein, R. L. (2018). New Insights into Island Vegetation Composition and Species Diversity-Consistent and Conditional Responses across Contrasting Insular Habitats at the Plot-Scale. Plos One, 13(7), 1-22.

Hendriyani, I., Wardhana, H. \& Hapsari, R. (2013). Kajian Alternatif Pembangunan Jembatan Penajam-Balikpapan. Jurnal Teknologi Berkelanjutan, 2(1), 6-20.

Hidayat, S. (2013). Kondisi Vegetasi di Kawasan Hutan Kebun Raya Balikpapan. Berita Biologi, 12(3), 345-357.
Husein, S. (2017). Lithostratigraphy of Tabul Formation and Onshore Geology of Nunukan Island, North Kalimantan. Journal of Applied Geology, 2(1), 25-35.

Karim, S., Jati, B. \& Mahfud, T. (2019). Application the Development of Balikpapan Bay Indonesia based on sustainable tourism. GeoJournal of Tourism and Geosites, 24(1), 29-38.

Keßler, P. J. A., \& Sidiyasa, K. (1999). Pohon -pohon Hutan Kalimantan Timur: Pedoman mengenal 280 jenis pohon pilihan di daerah Balikpapan-Samarinda. MOFEC-Tropenbos-Kalimantan Project.

Koutika, L. S. (2019). Afforesting Savannas with Acacia mangium and eucalyptus improves $\mathrm{P}$ availability in Arenosols of the Congolese coastal plains. Geoderma Regional, 16, 1-8.

Machado, M. R., Camara, R., Sampaio, P. de T. B., Pereira, M. G. \& Ferraz, J. B. S. (2017). Land Cover Changes Affect Soil Chemical Atttributes in the Brazilian Amazone. Acta Scientiarum Agronomy, 39(3), 385-391.

Mirmanto, E. (2014). Komposisi Floristik dan Struktur Hutan di Pulau Natuna Besar, Kepulauan Natuna. Jurnal Biologi Indonesia, 10(2), 201-2011.

Nugraha, R. \& Mustari, A. H. (2017). Karakteristik Habitat dan Jenis Pakan Kuskus Beruang (Ailurops ursinus) di Suaka Margasatwa Tanjung Peropa, Sulawesi Tenggara. Jurnal Wasian, 4(2), 55-68.

Odum, E. P. (1993). Dasar-dasar Ekologi. Yogyakarta: Gadjah Mada University Press.

Prasetyo, B. H., Suharta, N., Subagyo, \& Hikmatullah. (2001). Chemical and Mineralogical Properties of Ultisols of Sasamba Area, East Kalimantan. Indonesian Journal of Agricultural Science, 


\section{JURNAL BIDDJATI}

http://journal.uinsgd.ac.id/index.php/biodjati

\section{2(2), 37-47.}

Pusat Pengendalian Pembangunan Ekoregion Kalimantan. (2016). Daya Dukung Jasa Ekosistem Budaya Rekreasi dan Ekowisata Teluk Balikpapan (pp. 1-97).

Rachman, E. \& Hani, A. (2017). Potensi Keanekaragaman Jenis Vegetasi untuk Pengembangan Ekowisata di Cagar Alam Panjalu. Jurnal Wasian, 4(1), 01-10.

Rahayu, S., Basuni, S., Kartono, A. P., Hikmat, A. \& van Noordwijk, M. (2017a). Tree Species Composition of 1.8 ha Plot Samboja Research Forest: 28 Years After Initial Fire. Indonesian Journal of Forestry Research, 4(2), 95-106.

Russell, J. C., Meyer, J. Y., Holmes, N. D. \& Pagad, S. (2017). Invasive Alien Species on Islands: Impacts, Distribution, Interactions and Management. Environmental Conservation, 44(4), 359-370.

Shono, K., Davies, S. J. \& Kheng, C. Y. (2006). Regeneration of Native Plant Species in Restored Forests on Degraded Lands in Singapore. Forest Ecology and Management, 237(1-3), 574-582.

Sidiyasa, K. (2009). Struktur dan Komposisi Tegakan serta Keanekaragamannya di Hutan Lindung Sungai Wain, Balikpapan, Kalimantan Timur. Jurnal Penelitian Hutan Dan Konservasi Alam, 6(1), 79-93.

Sidiyasa, K. (2012). Karakteristik Hutan Rawa Gambut di Tuanan dan Katunjung, Kalimantan Tengah. Jurnal Penelitian Hutan Dan Konservasi Alam, 9(2), 125-137.

Sofiyanti, N., Iriani, D., Fitmawati \& Marpaung, A. A. (2019). Morphology, Palynology, and Stipe Anatomy of Four Common Ferns from Pekanbaru, Riau Province, Indonesia. Biodiversitas, 20(1), 327-336.
Soufian, F., Soemarno, Syekhfani \& Moehansyah. (2015). Soil and Vegetation Structure in Reclamation Area of Post-mining coal, Banjar Regency, South Kalimantan. Journal of Biodiversity and Environmental Sciences, 7(6), 196-206.

Stark, D. J., Nijman, V., Lhota, S., Robins, J. G. \& Goossens,B. (2012). Modelling Population Viability of Local Proboscis Monkey Nasalis larvatus Populations: Conservation implications. Endangered Species Research, 16, 31-43.

Suharta, N. (2010). Karakteristik dan Permasalahan Tanah Marginal dari Batuan Sedimen Masam di Kalimantan. Jurnal Litbang Pertanian, 29(4), 139-146.

Sulaeman, Suparto \& Eviati. (2005). Petunjuk Teknis Analisis Kimia Tanah, Tanaman, Air, dan Pupuk. Balai Penelitian Tanah.

Tata, M. H. L. \& Pradjadinata, S. (2013). Regenerasi Alami Hutan Rawa Gambut Terbakar dan Lahan Gambut Terbakar di Tumbang Nusa, Kalimantan Tengah dan Implikasinya Terhadap Konservasi. Jurnal Penelitian Hutan dan Konservasi Alam, 10(3), 327-342.

Taylor, S. \& Kumar, L. (2016). Global Climate Change Impacts on Pasific Islands Terrestrial Biodiversity: A review. Tropical Conservation Science, 9(1), 203-223.

Tchichelle, S. V., Epron, D., Mialoundama, F., Koutica, L. S., Harmand, J. M., Bouillet, J. P. \& Mareschal, L. (2017). Differences in Nitrogen Cycling and Soil Mineralisation between a Eucalyptus Plantation and a Mixed Eucalypt and Acacia mangium Plantation on a Sandy Tropical Soil. Southern Forests: A Journal of Forest Science, 79(1), 1-8.

Toma, T., Warsudi, Osone, Y., Sutedjo, Sato, T. \& Sukartiningsih. (2017). Sixteen Years Changes in Tree Density and Aboveground Biomass of a Logged 


\section{JURNAL BIDDJATI}

http://journal.uinsgd.ac.id/index.php/biodjati

and Burned Dipterocarp Forest in East Kalimantan, Indonesia. Biodiversitas, 18(3), 1159-1167.

Troia, A. (2012). Insular Endemism in the Mediterranean Vascular Flora: The case of the Aeolian Islands (Sicily, Italy). Biodiversity Journal, 3(4), 369-374.

Usman, E. \& Budiono, K. (2011). Identification of Hard Rock Based on Shallow Seismic Interpretation and Test for Foundation of Bridge at Balang Island, Balikpapan Bay, East Kalimantan. Bulletin of The Marine Geology, 26(1), $1-14$.

Wahyuni, I., Sulistijorini, Setiabudi, Meijide, A., Nomura, M., Kreft, H., ... Tjitrosoedirdjo, S. (2016). Distribution of Invasive Plant Species in Different Land-use systems in Sumatera, Indonesia. Biotropica, 23(2), 124-132.

Warsidi \& Endayani, S. (2017). Komposisi Vegetasi Mangrove di Teluk Balikpapan Provinsi Kalimantan Timur. Jurnal AGRIFOR, 16(1), 115-124.
Yassir, I. \& Arbainsyah. (2014). Diversity of Plant Communities in Secondary Succession of Imperata Grasslands in Samboja Lestari, East Kalimantan, Indonesia. Indonesian Journal of Forestry Research, 1(2), 139-149.

Yassir, I, van der Kamp, J. \& Buurman, P. (2010). Secondary Succession After Fire in Imperata Grasslands of East Kalimantan, Indonesia. Agriculture, Ecosystems and Environment, 137(1), 172-182.

Yassir, I. \& Buurman, P. (2015). Soil Organic Matter Dynamic upon Secondary Succession in Imperata Grassland, East Kalimantan, Indonesia. Indonesia Journal of Forestry Research, 2(1), 43-53.

Yuliana, E. D. (2012). Jenis Mineral Liat dan Perubahan Sifat Kimia Tanah Akibat Proses Reduksi dan Oksidasi pada Lingkungan Tanah Sulfat Masam. Jurnal Bumi Lestari, 12(2), 327-337. 